\title{
Relationship Between National Cultural Distance And The Performance Of Multinationals In The Nigerian Petroleum Sector
}

\author{
Tega Douborapade Peretomode \\ Human Resources Department \\ Notore Chemical Industries, Port Harcourt, Nigeria
}

\begin{abstract}
The aim of this study was to examine if and how national cultural difference affects the performance of multinationals in the Nigerian petroleum sector. A sample of 33 multinationals present in the Nigerian petroleum sector were used in this research. Information such as their home country, number of years in operation in Nigeria, number of employees, performance, cultural distance, and their annual sales made up the variables used in this study. The data collected were put into SPSS Statistical analysis programme and mean, standard deviation, spearman rho and multiple regressions were used to test the hypothesis. The result showed that as cultural distance between home Countries and Nigeria increases, there was a negative impact on the performance of multinationals in the Nigerian petroleum sector. Although the results imply that cultural distances exit and can have a negative impact on the performance of multinationals, if properly managed, such negative impacts can be minimized and multinationals can be successful regardless of been present in a culturally distant home country.
\end{abstract}

Key Words: Cultural dimension, Cultural distance, cultural diversity, multinationals, national culture, performance, petroleum sector, manufacturing sector.

\section{Introduction}

Culture is a complex phenomenon. As a result there is no one universally accepted definition. It simply refers to the way of life of a people, the sum total of learned beliefs, values and customs or artifacts that serve to direct individual behaviour of members of a particular society (Peretomode, 2012). It is an integrated phenomenon that is formed from components that include conscious and unconscious values, ideas, attitude, laws, processes, history, symbols, language, education, religion, rituals, morals, customs, art, knowledge and habits acquired by a man as a member of society (Firoz et al, 2002; Miroshnik and Frost, 2000). Hofstede, (1980:21) defines culture simply as the "collective programming of the mind which distinguishes members of one human group from another" or of one nation from another. According to Hofstede (1991), national culture is the patterns of feeling, thinking and acting acquired by growing up in a particular country. The environment within which one grows up will therefore mold ones personal behaviour and attitudes towards different aspects of living. This, according to Hofstede (1991), has given rise to attributing of certain qualities to the citizens of a particular country, with people being referred to a "typical Nigerian" or a "typical Russian".

It could be argued that no two cultures are exactly the same. Culture may share similarities with another but the extents to which such similarities exist vary from country to country. The extent to which national cultures share similarities or differ from one another is termed national cultural difference, also referred to as national cultural distance. Moresini et al (1998) defined cultural distance as the extent to which cultural norms and practices in one Country are different from cultural norms and practices in another Country.

\section{REVIEW OF LITERATURE}

There are a number of business and management cultural models and theories that serve as fundamentals and stepping stone into understanding culture in the context of International Business. These theories include those of Edward T. Hall's cultural continuum, Fons Trompenaar's. Cultural dimensions and Geert Hofstede's dimensions of work-related variables. Hofstede's model is the most widely known and most comprehensive and methodologically supported theory of national cultures and how their diversity can affect behaviour and consequently performance in the work place (Hoecklin 1995; Tzeremes et al, 2008). For this reason, Hofstede's model has been adopted in this study. The Hofstede model (1980; 2005) identified five dimensions namely: power distance, (from low to high), uncertainty avoidance (from weak to strong), Collectivism versus individualism, masculinity versus femininity, and long-term versus short - term Orientations.

Multinationals are firms that carry out business operations internationally to reach and satisfy markets in other countries as well as take advantage of resources available in these countries. The role of national cultural differences and the effect if has on the performance of multinationals is one that has been debated for 
the longest time with researchers and scholars taking various stand points in respect to whether national culture plays a major role in affecting the performance of multinationals and how (Tzeremes and Halkos, 2008). Companies undertaking business practices across national boundaries will need to make room for the differences that exist between their culture and that of the country they are venturing into as failure to do this is evident in the increasing number of management blunders that can be seen in the world of international business (Miroshnik 2002 and Morden 1995). Results of a research by Newman and Nollen (1996) also show that different national cultures require different management practices as there is no one best way of management that will work across all cultures.

According to Newman and Nollen, when management practices are in synchrony with national cultures, multinationals gain competitive advantage from an effectively aligned external environment and internal structure and failure to do so will have an adverse effect on performance. The wider the cultural distance, the more costs a multinational will incur and therefore leading to reduced performance.

The Nigerian Petroleum Industry dates back to 1956 when production of oil started in Olobri. As of 2004, Nigerian Oil Production was 2.5 million barrels per day and strategies were put in place to raise production to four million barrels per day (NNPC, 2010). A report by the United Nations Conference on Trade and Development( UNCTD, 2008) ranked Nigeria $16^{\text {th }}$ in the world's list of Oil Producing countries. This rich and vibrant sector of the nation has attracted a number of large multinationals from different regions of the world as at 2007 (Herald 2008) and accounts for more than 50\% of the country's economy, making it the most significant source of income (NNPC 2010).

\section{Application of Hofstede's Model to the Nigerian Culture (Host Country).}

Nigeria is composed of 250 ethnic groups speaking over 500 languages including English, with a number of religious practices with 50\% of the population as Muslims, $40 \%$ as Christians and $10 \%$ as indigenous beliefs (Central Intelligence Agency, 2012). The table below shows Nigerian Scores across Hofstede's cultural dimensions.

TABLE 1. Nigerian Scores Across Hofstede's Cultural Dimensions

\begin{tabular}{|l|l|l|l|l|l|}
\hline Dimensions & $\begin{array}{l}\text { POWER } \\
\text { DISTANCE } \\
\text { (PDI) }\end{array}$ & $\begin{array}{l}\text { UNCERTAINTY } \\
\text { AVOIDANCE } \\
\text { (UAI) }\end{array}$ & $\begin{array}{l}\text { INDIVIDUALISM } \\
\text { VS } \\
\text { COLLECTIVISM }\end{array}$ & MASCULINITY & $\begin{array}{l}\text { LONG TERM } \\
\text { ORIENTATION } \\
\text { (LTO) }\end{array}$ \\
\hline SCORES & 77 & 54 & 20 & 46 & 16 \\
\hline RANK & $17-18$ & 52 & $56-61$ & $41-42$ & 37 \\
\hline
\end{tabular}

From the Hofstede's scores and ranking, with a ranking of $17-18$ out of 74 Countries, high power distance is quite evident in the Nigerian culture. In the Nigerian culture, for example, children are expected to obey their parents regardless of the situation hence challenging a parent or an elder is frowned upon and seen as disrespectful. Similarly, in the work place, superiors and managers consider themselves as unequal and superiors are therefore entitled to more privileges (Hofstede, 2005), and subordinates willingly obey their superiors. In terms of uncertainty avoidance, the Nigerian culture can be categorized as medium to low as the highest country scored 112 and Nigeria scored 54. With such a ranking, the Nigerian culture will tilt towards low uncertainty avoidance more but with a few characteristics of high uncertainty avoidance. In Nigerian culture, formal rules are disliked but obeyed when there is necessity.

The Table 2 shows that Nigerian is a collective society as it scored 20 on individualism which is low and ranked $56-61$ out of 74 countries. Having a collective culture, Nigerian families tend to have extended family members (Hofstede, 2005) and as a result of growing up in a group, personal opinions hardly exist as people constantly seek the ideas and opinions of the group to which they belong. In the masculinity vs. femininity, Nigeria scored 46 out of 110 and ranked $41-42$ out of 74 which makes medium to low in terms of masculinity (Hofstede, 1995). With such rankings Nigeria is seen as possessing a combination of feminine and masculine characteristics of culture but more of the feminine characteristics. Further, the Nigerian culture can be categorized as being a short term oriented culture as it scored low in the long term orientation dimension. As a short - term oriented culture, children are brought up to recognize the immediate needs and impact of decisions and react accordingly (Hofstede, 2005). 
Table 2: Application of Hofstede's Model to Home Countries

\begin{tabular}{|l|l|l|l|l|l|}
\hline Country & $\begin{array}{l}\text { PDI Power } \\
\text { distance }\end{array}$ & $\begin{array}{l}\text { IDY } \\
\text { Individualism }\end{array}$ & $\begin{array}{l}\text { MAS } \\
\text { Masculinity }\end{array}$ & $\begin{array}{l}\text { UAI Uncertainty } \\
\text { Avoidance }\end{array}$ & $\begin{array}{l}\text { LTO Long } \\
\text { Term }\end{array}$ \\
\hline UK & 35 & 89 & 66 & 35 & 25 \\
\hline US & 40 & 91 & 62 & 46 & 29 \\
\hline France & 68 & 71 & 43 & 86 & \\
\hline Switzerland & 34 & 68 & 70 & 58 & \\
\hline Germany & 35 & 67 & 66 & 65 & 31 \\
\hline South Africa & 49 & 65 & 63 & 49 & 61 \\
\hline India & 77 & 48 & 56 & 40 & \\
\hline Italy & 50 & 76 & 70 & 75 & 44 \\
\hline Netherland & 38 & 80 & 14 & 53 & 16 \\
\hline Nigeria & 77 & 20 & 46 & 54 & \\
\hline
\end{tabular}

The aim of this section is to try to compare the scores of each home country to the scores of Nigeria across all of Hofstede's dimensions. From the list of countries involved in this study, the highest power distance score was India with 77 and the lowest Switzerland with 34. Taking the Nigerian power distance score of 77 into consideration, Countries like India, France, South Africa and Italy may experience little if any difficulty in adapting to the Nigerian culture as far as this dimension is concerned. On the other hand, US, UK, Switzerland, Netherland and Germany with the lower power distance scores will need to learn and adapt to the Nigerian high power distance environment. This interpretation should be applied to the other dimensions based on the dimension's scores compared to that of Nigeria.

\section{STATEMENT OF THE PROBLEM}

The role of national culture on performance of multinationals is one that has been debated by scholars and researchers. Different scholars take different stands. Some see the role of culture as being overstated and insignificant to the performance of multinationals, some believe multinationals cannot be successful without taking cultural diversity into consideration and others identify a positive or negative effect of national cultural differences on the performance of multi-nationals but an analysis of various cultural diversity has an impact on the performance of multinationals. As at 2008 (UNCTAD LIST), 29 of the world's 100 largest multinationals and nine (9) of the top 50 largest multinationals from developing countries were present in Nigeria. As at 2008 (UNTAD LIST) a total of 38 multinationals from 12 different Countries were present in Nigeria. These comprises of 29 of the world's 100 largest and nine (9) of the top 50 largest multinationals from developing countries. Using the Hofstede's Model and Kogut and Singh's composite index, one question that may be asked is, what kind of relationship exists between national cultural differences and the performance of multinationals in the petroleum sector of the Federal Republic of Nigeria, and how?

\section{Null Hypothesis}

Ho. There is no relationship between cultural distance and the performance of multinationals in the Nigerian Petroleum Sector.

\section{Methodology}

The research aims to measure how wide or narrow distance between cultures affects the performance of multinationals. Therefore, the independent variable is the cultural distances between each affiliate home country culture and the Nigerian culture. There already exist various cultural distance measures by Kogut and Singh (1988) as discussed previously and in Hofstede's dimension of culture. The dependent variable in this research is the performance of the multinationals over a three year period to 2008. According to Kessapidou and Varsakelis (2002), three year period helps to avoid fluctuations in economic activities a country experiences over a period of time. Performance in this research will be measured by computing the average sales over a three year period for each affiliate. Size and experience will be incorporated as control valuables as they are some factors capable of impacting on performance (Kessapidou and Varsakelis, 2002; Morosini et al, 1998). The size of each affiliate will be determined by the number of employees and experience by the number of years the multinational has operated in Nigeria from the year of establishment to 2009.

\section{Research Strategy}

This research is based on a case study strategy (Nigerian Petroleum Sector) and an explanatory approach. Case study is a research strategy that emphasizes on understanding the dynamics present within a single setting (Eisenhardt, 1989) which is the petroleum sector in this case. It is often linked to the exploratory 
and explanatory research. Explanatory studies refer to research that emphasizes on studying a situation by establishing relationship between variables in order to explain the situation (Saunders et al, 2009).

\section{Sample size}

In picking the sample from the population of 38 multinationals from 12 different countries, emphasis was put on representing all of the 10 countries identified in the sample frame with at least two companies. This reduced the number to 33 multinationals from 9 countries, United States, United Kingdom and France had the largest number of multinationals, so they were represented with more than two companies. South Africa has two, and the other countries were represented with one company each as well.

\section{Data Collection}

The research made use of quantitative data which was collected through secondary data drawn from a wide variety of sources including:

- UNCTAD database provided data on the list of multinationals in Nigeria.

- University Bloomberg and Data Stream provided database from where the dependent and control variables were drawn and compared.

- Books and journals provided data and information on the literature required to cover culture and performance of multinationals.

\section{Validity and Reliability}

Validity and reliability in research that uses secondary data owes a lot to the source and method of data collection (Saunders et al 2009). One way this research increased validity is through the use of control variables in its analysis. In this research, reliability was determined through comparing data across a number of databases and carrying out significance testing with a significance level of 0.05 .

\section{Data Analysis, Findings and Discussion}

The table 3 below provides general information of cases.

Table 3: General Information of cases

\begin{tabular}{|l|l|l|}
\hline COUNTRY OF ORIGIN & NO. OF FIRMS & $\begin{array}{l}\text { CULLTURAL } \\
\text { DISTANCE FROM } \\
\text { NIGERIA }\end{array}$ \\
\hline United States of America & 10 & 3.71 \\
\hline United Kingdom & 9 & 3.99 \\
\hline France & 4 & 2.70 \\
\hline Switzerland & 2 & 3.04 \\
\hline Germany & 2 & 2.63 \\
\hline Italy & 2 & 2.50 \\
\hline India & 2 & 2.52 \\
\hline South Africa & 1 & 2.06 \\
\hline Netherlands & 1 & 3.98 \\
\hline
\end{tabular}

Both descriptive and inferential statistics were used to analyze the data.

The table 4 below shows the minimum, maximum, mean and standard deviations of the sample variables; performance, experience, number of employees and cultural distance using SPSS programme. The mean of performance is 47.52 and the mean of cultural distance is 3.37. The mean experience is 45.30 and that for employees is 471.59 . Furthermore, the standard deviation enabled us to identify the extent to which the data were scattered around the mean.

Table 4: Descriptive Statistics

\begin{tabular}{|l|l|l|l|l|l|}
\hline & N & Minimum & Maximum & Mean & Std. Deviation \\
\hline Performance in Mil Naira & 33 & 31 & 83 & 47.52 & 12.633 \\
No. of employee & 33 & 198 & 820 & 471.59 & 149.350 \\
Cultural Distance & 33 & 2.06 & 3.99 & 3.3185 & .60876 \\
Experience & 33 & 5 & 86 & 45.30 & 21.498 \\
Valid N (listwise) & 33 & & & & \\
\hline
\end{tabular}


In addition, based on results form Table 5 the Shapiro - Wilk Sig. values for employees and experience are above .05 showing that they are normally distributed and performance and cultural distance violates the assumption of normal distribution and performance and cultural distance violates the assumption of normal distribution as their values are less than significant at less than .05. For the Kolmogorov Smirnov statistic, performance and employees are above .05 showing a normal distribution and cultural distance and number of years is below .05 making them not normally distributed. Normal distribution is required if the analysis of a data set is to be done by regression.

Table 5: Normality Tests

\begin{tabular}{|l|l|l|l|l|l|c|}
\hline \multirow{2}{*}{} & \multicolumn{3}{|l|}{ Kolmogorov-Smirnov $^{\mathrm{a}}$} & \multicolumn{2}{l|}{ Shapiro-Wilk } \\
\cline { 2 - 7 } & Statistic & df & Sig. & Statistic & df & Sig. \\
\hline Performance & .129 & 33 & .179 & .918 & 33 & .016 \\
Employees & .098 & 33 & .200 & .979 & 33 & .746 \\
Cultural distance & .285 & 33 & .000 & .848 & 33 & .000 \\
Experience & .154 & 33 & .045 & .940 & 33 & .069 \\
\hline
\end{tabular}

a. Lilliefors Significance Correction

* This is a lower bound of the true significance.

\section{Multiple Regressions}

In science and social science, multiple regression is used to analyse the strength of the relationship between variables. It specifies how much of the variation or change in a dependent variable is associated with or caused by the independent variable(s) (Saunders et al 2009). The multiple regression is a powerful statistical process as it gives you the relative contribution of every independent variable in a research.

Table 6: Model Summary

\begin{tabular}{|l|l|l|l|l|}
\hline Model & $\mathrm{R}$ & $\mathrm{R}$ Square & $\begin{array}{l}\text { Adjusted } \\
\text { Square }\end{array}$ & Std. Error of the Estimate \\
\hline 1 & $.585^{\mathrm{a}}$ & .342 & .274 & 10.761 \\
\hline
\end{tabular}

a. Predictors: (Constant), Experience, No. of employees, Cultural Distance.

Table 7: Anova table

a. Predictors: (Constant), Experience, No. of employees, Cultural Distance

\begin{tabular}{|l|l|l|l|l|l|}
\hline Model & Sum of Squares & df & Mean Square & F & Sig. \\
\hline $\begin{array}{lllll}\text { Regression } \\
\text { Residual }\end{array}$ & 1748.588 & 3 & 582.863 & 5.033 & $.006^{\mathrm{a}}$ \\
Total & 3358.232 & 29 & 115.801 & & \\
& 5106.821 & 32 & & & \\
\hline
\end{tabular}

b. Dependent Variable: Performance in Mil Naira

Table 8: Multiple Regression Coefficients Table

\begin{tabular}{|c|c|c|c|c|c|c|}
\hline \multirow[b]{2}{*}{ Mode } & & \multicolumn{2}{|c|}{ Unstandardized Coefficients } & $\begin{array}{l}\text { Standardized } \\
\text { Coefficients }\end{array}$ & \multirow[b]{2}{*}{$\mathrm{t}$} & \multirow[b]{2}{*}{ Sig. } \\
\hline & & $\mathrm{B}$ & Std. Error & Beta & & \\
\hline & (Constant) & 55.430 & 13.408 & & 4.134 & .000 \\
\hline & No. of employees & .043 & 013 & .505 & 3.285 & .003 \\
\hline & Cultural Distance & -6.583 & 3.202 & -.317 & -2.056 & .049 \\
\hline & Experience & -.137 & .092 & -.233 & -1.480 & .150 \\
\hline
\end{tabular}

a. $\quad$ Dependent Variable: Performance in Mil Naira 
Looking at the Beta Column of the standardized coefficients, the largest Beta coefficient is that of number of employees (0.505). This shows that this variable makes the highest contribution towards changes in the dependent variable. The Beta value for cultural distance is (-0.317) indicating that this made less contribution to changes in the dependent variable. The Beta value for cultural distance is (-0.317) indicating that this made less contribution to changes in the dependent variable in comparison to number of employees and the Beta value for Experience is close to zero (0.092) indicating that it made no relevant contribution to the dependent variable. For cultural distance, the Sig, value is 0.49 which is less than 0.05 (the $95 \%$ confidence level) showing the cultural distance variable makes a significant unique contribution to the prediction of the dependent variable. Number of employees also makes a significant unique contribution to the dependent variable as the Sig. value is less than $0.05(0.003)$. On the other hand, the experience is not making a significant unique contribution to the prediction of the dependent variable as the Sig. value is greater than $0.05(0.150)$.

\section{Spearman's Rank Order Correlation}

Spearman's rank order correlation is the ideal statistical analysis for testing the hypothesis in this research. It's values range from -1.00 to +1.00 with the sign preceding the correlation value indicating the direction and strength of the relationship between the variables (a negative sign indicating a negative relationship). And the higher the ' $r$ ' value (value of the correlation coefficient) the stronger the relationship between the variables.

Table 9: Correlation Table

\begin{tabular}{|c|c|c|c|c|c|}
\hline & Correlations & $\begin{array}{l}\text { Performan } \\
\text { ce in Mil } \\
\text { Nira }\end{array}$ & $\begin{array}{l}\text { Cultural } \\
\text { Distance }\end{array}$ & $\begin{array}{l}\text { No. of } \\
\text { employee } \\
\text { s }\end{array}$ & $\begin{array}{l}\text { Experie } \\
\text { nce }\end{array}$ \\
\hline $\begin{array}{l}\text { Spearman's } \\
\text { Coefficient rho } \\
\mathrm{N}\end{array}$ & $\begin{array}{l}\text { Performance in Mil Correlation } \\
\text { Naira Sig (2-tailed) }\end{array}$ & $\begin{array}{l}1,000 \\
33\end{array}$ & $\begin{array}{l}-.345 \\
\\
.050 \\
33\end{array}$ & $\begin{array}{l}.365 \\
.037 \\
33\end{array}$ & $\begin{array}{l}.114 \\
\\
.527 \\
33\end{array}$ \\
\hline $\begin{array}{l}\text { Cultural Distance } \\
\mathrm{N}\end{array}$ & $\begin{array}{l}\text { Correlation Coefficient } \\
\text { Sig. (2-tailed) }\end{array}$ & $\begin{array}{l}-.345 \\
.050 \\
33\end{array}$ & $\begin{array}{l}1.000 \\
33\end{array}$ & $\begin{array}{l}-048 \\
.790 \\
33\end{array}$ & $\begin{array}{l}-.059 \\
.744 \\
33\end{array}$ \\
\hline $\begin{array}{l}\text { No. of employees } \\
\text { N }\end{array}$ & $\begin{array}{l}\text { Correlation Coefficient } \\
\text { Sig. (2-tailed) }\end{array}$ & $\begin{array}{l}.365 \\
.037 \\
33\end{array}$ & $\begin{array}{l}-.048 \\
.790 \\
33\end{array}$ & $\begin{array}{l}1.000 \\
33\end{array}$ & $\begin{array}{l}.208 \\
.245 \\
33\end{array}$ \\
\hline $\begin{array}{l}\text { Experience } \\
\mathrm{N}\end{array}$ & $\begin{array}{l}\text { Correlation Coefficient } \\
\text { Sig. (2-tailed) }\end{array}$ & $\begin{array}{l}-.114 \\
.527 \\
33\end{array}$ & $\begin{array}{l}-.059 \\
.744 \\
33\end{array}$ & $\begin{array}{l}.208 \\
.245 \\
33\end{array}$ & $\begin{array}{l}1.000 \\
33\end{array}$ \\
\hline
\end{tabular}

Correlation is significant at the 0.05 level (2-tailed).

As shown by the table 9 above, there is a negative relationship between cultural distance (independent variable) and performance (dependent variable). The negative value indicates that the cultural distance and performance vary in opposite direction such that as cultural distance increases, performance decreases and vice versa. The correlation coefficient of cultural distance and performance is -0.345 with a Sig. value of 0.050 indicating a medium negative correlation between the two variables. As a result, the null hypothesis is rejected. Furthermore, the correlation coefficient of number of employees and performance is 0.365 with a Sig. value of $0.037(<0.05)$ indicating a medium positive correlation between the variables. The Sig. value of the correlation between experience and performance $(0.527)$ shows that experience is not significantly related to performance.

\section{Discussion of Findings}

The purpose of this research was to examine whether the findings would indicate an association between national cultural distance and performance of multinationals and if so, how? The hypothesis was tested using Spearman's Rank Order Correlation, which showed that there is a negative correlation between cultural distance and the performance of multinationals in the Nigerian Petroleum sector. Spearman's correlation coefficient of -0.345 indicates that the existing negative relationship is medium. This negative relationship means that the higher the national cultural distance, the lesser the performance of multinationals in the Nigerian petroleum sector. 
As far as the hypothesis was concerned, our findings support the alternate hypothesis which states that there is a relationship between cultural distance and performance, and it further identifies that this relationship between cultural distance and performance is negative. This result opposes the assumption of the literature that cultural distance plays no role in determining the performance of multinational subsidiaries (Bhardwaj et al 2007), Buckley and Lessard (2005), Corn and Kanter (1994), Merchant and Ban der Stede (2003) and Sullivan (1994). It also opposes the literature that a wider cultural distance will have a positive influence on performance of multinationals(Miroshnik 2002, Corn and Kanter 1994). This research, however, concurs with the results of (Hofstede 1980, Kogut and Singh 1988, Zaheer 1995. Halkos \& Tzeremes 2008). Kessapidou and Varsakelis (2002), Newman and Nollen (1996) argues that multinationals from countries with small cultural distance perform better than multinationals from countries with large cultural distances.

Different national cultures have different ways of managing and structuring their work environment and members of different national cultures react differently to products and marketing strategies both of which contribute to the sales (performance of a multinational. According to Hofstede (1991), no two cultures are exactly the same. The Nigerian culture is very diverse as cited in the literature review consisting of different cultures - traditions, beliefs, ideologies and norms. The east is different form the west and the north is different from the south, making it more difficult and expensive, for multinationals must have to adapt to the market. According to Zaheer (1995), Halkos and Tzeremes (2008), Frost (2000), multinationals incur costs when they try to adapt to a new market of which developing communication means to promote a global brand is one of them. In the case of Nigeria, different communication means and adaptation techniques will need to be used for the differences that exist within the country thus further increasing the cost multinationals continue to incur.

Furthermore, on the discussions, it is quite impossible to ignore the fact that Nigeria is a highly collectivistic culture (IDV score - 20) while the home countries of most of these multinationals have an individualistic culture (US - 91, UK - 89, France, - 76). The countries with the highest number of subsidiaries in Nigeria are all from highly individualistic cultures with the United States ranked as the highest in the world. With the wide disparity between Nigeria and the home countries of most of these multinationals, it is not unexpected that the results between performance and cultural distance are negative. According to Triandis (1989), the individualism/collectivism dimension plays a major role in the performance of cross cultural teams. Individualism is concerned with the empowering of employees and collectivism on the other hand is concerned with group decision making. In the case of the Nigerian petroleum sector, employees from America, United Kingdom or France, may experience difficulties in blending in to group works (based on the collectivistic culture) or even if they did may not understand how to behave within these groups. This can cause problems within a team, affecting their ability to be productive which will in turn have a negative impact on the performance of the multinational's Nigerian subsidiary. This supports an argument by Ngo et al (1998) which explains that multinationals from countries with different cultural values and practices are better able and find it easier to adapt to local conditions than multinationals from other countries with different cultural values and practices. This implies that most of these multinationals may be experiencing difficulties in adapting to the work environment as a big difference exists in what they are used to thus contributing to their inability to perform better.

But in explaining the negative relationship between cultural distance and performance as presented by the analysis, one cannot ignore the fact that the countries with the highest number of companies possess the highest cultural distance from Nigeria (USA 10 companies, cultural distance 3.71 and United Kingdom 9 companies, cultural distance 3.99) indicating that regardless of the negative impact cultural distance may have on performance, certain factors still attract multinationals to invest in culturally distance Countries. This can be interpreted from the multiple regressions in the analysis where the Beta value of cultural distance was -0.314 implying that cultural distance contributed only $31 \%$ to changes in performance of multinationals. This can be due to a number of factors.

Firstly, the world is becoming a global village, geographical distance and barriers to cross border trade have reduced making people and countries more open to new products, ideas, cultures and practices that are different from what they perceive as normal (Bhardwaj et al 2007 and Ohmae 1989). This ease in movement and transfer of skills, technology and finances, have contributed to companies becoming multinationals even though their target host country may be culturally distant. Secondly, there is the famous "Diamond model of national advantage" which explains that multinationals are attracted to invest in countries that posses certain advantages that are unique to that country. This could be either nearness/availability of natural resources, cheap labor or ease in acquiring capital (Dess et al ,2009). For instance, Nigeria is naturally blessed with abundance of crude oil and gas and has therefore attracted a large number of multinationals. From the sample used in the research, 10 of the multinationals were from the United States and nine(9) were from the United Kingdom. This implies that despite the wide cultural distance that exists between both countries, this multinationals stand to gain from the abundant petroleum resources available in Nigeria and hence has decided to invest. But in multinational been attracted to invest in countries that are culturally distant due to availability of resources and other factors, 
putting in an effort to work with the existing cultural differences is key to the success of these multinationals and cannot be ignored.

\section{Implications for Management and Recommendations}

The objective of this study was to find out if the relationship between cultural distance and the performance of multinationals based on assertions of the literature review can also be applied in a Sub-Saharan African country like Nigeria. The result of this research showed that there is a negative relationship between the variables. Meaning performance, to an extent, is based on the degree of cultural distance between home and host country. However, the results and data also showed that regardless of the negative impact cultural distance has on the performance of multinationals, quite a number of multinationals present in the Nigerian petroleum sector are from home countries that are culturally distant. And this can be due to a number of reasons; globalization, world presence, search for better market and availability of resources. With this, it is quite evident that becoming a multinational corporation has increasingly become part of most business operations and therefore, managers and businesses need to find a way to work around these cultural differences and decrease their cons while increasing the pros of becoming multinationals.

Based on the findings from the study, some implications for and recommendations for management are proposed towards the management of cultural distance in order to reduce the negative impact it has on the performance of multinationals.

Due to differences in culture, norms, practices, economy and history, managers and both senior members of organizations and subordinates must understand that these cultural differences affect the way employees relate and behave in the work place and should therefore make room for the existence of such differences while taking into consideration the possible problems that it could generate and have procedures on how to effectively deal with these problems should they arise.

Also in becoming multinationals, a proper market survey and analysis should be put in the budget carried out before actually investing in the market and what the market expects from them. With a proper understanding of these, managers can then put appropriate strategic plans in place on how to penetrate the market within the confines of their culture and how much change they are willing to accept. This reduces chances of negative unforeseen circumstances that can have a negative impact on the firm's ability to reach its goals and work at full potential.

Furthermore, although there is the belief that with the concept of the "borderless environment" and the world becoming a "global village", multinationals can afford to be less bordered about differences in the individual national cultures (Ohmae 1989). Halkos and Tzeremes (2008) argue that multinationals cannot exist in isolation from the cultures of the countries within which they operate. This is so because the national culture defines the way of life of the people multinationals intend to target; therefore selling to them with an approach which is different from what their cultural environment accepts would not appeal to them. Hence, as mentioned earlier, companies will need to embrace the reality of cultural diversity among the different national cultures of the countries they enter as international or multinational cooperation's and create room for the relative influence of this difference on their performance (Morden 1995).

\section{Conclusion}

This research presented evidence that cultural distance may serve as a hindrance to the performance of multinationals; it does not prevent companies from investing globally in culturally distant countries as such cultural differences can be minimized with the appropriate management techniques and approaches. More so, companies investing in going global might as well invest in managing such cultural differences especially when their target country has abundance of natural resource, availability of cheap labor or the ease of capital acquisition. In addition, multinationals interested in venturing into the Nigerian petroleum sector should be able to identify the sort of relationship that exists between cultural distance and performance in this sector and possible reasons why such relationship exists. This will give them an insight on how to best prepare and what to take into consideration in order to reduce this negative impact and increase their performance. 


\section{Reference:}

[1] Bhardwaj, A., Dietz, J. and Beamish, P.W. (2007). Host country cultural influences on foreign direct investment. Management International Review. 47(1) 9-50.

[2] Brouthers, K.D. and Brouthers, L.E. (2000). Explaining the national culture paradox. Journal of International Business Studies. 32(1) 177-189.

[3] Buckley, P.J. and Lessad, D.R. (2005). "Regaining the edge of international business research" Journal of international Business Studies. 36 (6).595-9.

[4] Central intelligence Agency. (2010). The world factbook. Available at https://www.cia.gov/library/publications/the-worldfactbook/geos/ni.htm1 (Accessed 7th May, 2012).

[5] Corn, I. R. and Kanter, M.R. (1994). Do cultural differences make a business differences? Contextual factors affecting crosscultural relationship success. Journal of Management Development 13 (2)5-23

[6] Dess, G.G., Lumpkin, G.T. and Eisner, A.B. (2009). Strategic management text and cases (4 ${ }^{\text {th }}$ edn). Irwin: McGraw Hill.

[7] Eisenhardt, K.M. (1989). Making fast strategic decisions in high-velocity environments. Academy of management journal. (32)( 3). $543-579$.

[8] Firoz, N.M., Kim, K.H. and Maghrabi, A.S. (2002). Think globally, manage culturally. International Journal of Cultural management. 12 (3\&4)32-50.

[9] Frost, A.R. (2000). Negotiating culture in a global environment. Journal of communication Management. 4 (4)369-377.

[10] Hoecklin, L. (1995). Managing cultural differences, strategies for competitive advantage. Economc Intelligence unit: Addisonwesley publishing company.

[11] Hofstede, G. (1991). Cultures and organization: software of the mind. London: McGraw-Hill.

[12] Hofstede, G. (1993). Cultural constraints in managing theories. The Academy of management Executive. 7( 1), 81-94

[13] Hofstede, G. and Hofstede, G.J. (2005). Cultures and organizations: software of the mind. (2 edn.)New York: Mcgraw Hill.

[14] Hofstede, G. (2001). Cultures consequences: comparing value, behaviours, institutions and organizations across nations. London: Sage Publications.

[15] Hofstede, G.(1980). Culture's consequences: international difference in work-related values. Beverly Hills, CA: sage publications.

[16] Hofstede, G.(1994). The business of international business is culture. International Business Review 3 (1). 1-14.

[17] Hofstede, G.(2003).What is culture? A reply to Baskerville. Accounting, organization and society. $28,811-813$.

[18] Kessapidou, S. and Varsakelis, N.c. (2002). The impact of national culture on international business performance: the case of foreign firms in greece. European Business Review. 14( 4), 268-275.

[19] Kogut, B. and Singh, H. (1988). The effect of national culture on the choice or entry mode. Journal of International Business Studies. 19(3), 411-432.

[20] McSweeney, B. (2002). Hofstede's model of national cultural difference and their consequences: A triumph of faith - a failure of analysi. Human relations. 55 (1), $98-118$.

[21] Mead, R. (998). Internation management cross - cultural dimensions. (2 ${ }^{\text {nd }}$ edn) Victoria: Blackwell Publishing

[22] Merchant, K.A. and Van Der Stede, W.A. (2003). Management control systems Performance measurement, evaluation and incentives. New York: Prentice Hall.

[23] Miroshink, V. (2002). Culture international management: a review. Journal of Management Development. 21 (7), 521 -544.

[24] Morden, T. (1995). National culture and the culture of the organization. Cross cultural Management: an International Journal. 2 (2), 3-12.

[25] Morosini, P., Shane, S. and Singh, H. (1998). Cultural distances and cross-border acquisition performance. Journal of International Business Studies. 29 (1) 137-158

[26] Ngo, H., Turban, D., Lau, C. and Lui, S. (1998). Human resource practices and firm performance of multination corporations: influence of country origin. International Journal of Human Resource Management 4 (8), 22-44

[27] Ohmae, K. (1989). Management in a borderless world. Harvard Business Review 67(3), 152-16

[28] Padmanabhan, P. and Cho, K. R. (2005). Revisiting the role of cultural distance in MNC's foreign ownership mode choice: the moderating effect of experience attributes. International Business Review, 14 (3), 307-324

[29] Peretomode, V.F. (2012). Theories of management: Implications for educational administration: Benin City: Justice - Jeco Global Publishers and printers Ltd.

[30] Saunder, M., Lewis, P. and Thornhill, A. (2009). Research methods for businenss students. (5 ${ }^{\text {th }}$ edn). London: Finacial Times Pitman Publishing.

[31] Schuster, C.P. and Copeland M.J. (2008). Cultural theory in use: the intersection of structure, process and communication in business practice. Journal of Public Affairs 8 (1), 261-280.

[32] Shane, S. (1994). The effect of national culture on the choice between licensing and FDI. Strategic Management Journal 15 (8), $627-642$

[33] Sullivan, D. (1994), The "threshold of internationalization": Replication, extension and reinterpretation. Management International Review 34 (2) $165-186$

[34] Triandis, H.C. (1989). The self and social behaviour in differing cultural contexts. Psychological Review $96,506-520$

[35] Trompenarrs, F and Hampden- Turner, C. (1997). Riding the waves of culture, Understanding cultural diversity in business. (2 edn). London: Nicholas Brealey Publishing.

[36] Tzeremes, N.G. and Halkos, G.E. (2008). Does the home country's national culture affect MNC'S performance? Empirical evidence of the world's top 100 east - west non-financial MNC'S. Global Economic Review 37 (4) 405-427

[37] Zaheer, S. (1995). Overcoming the liability of foreignness. Academy of Management Journal 38 (2) 341 -363. 